\title{
A Systematic Review of the Use of Organization and Management Theories in Climate Change Studies
}

\author{
Tiberio Daddi, ${ }^{1 * *}$ Niccolò Maria Todaro, ${ }^{1}$ Maria Rosa De Giacomo ${ }^{2}$ and Marco Frey ${ }^{1}$ \\ ${ }^{1}$ Sant'Anna School of Advanced Studies, Institute of Management, Pisa, Italy \\ ${ }^{2}$ UCL Institute for Sustainable Resources, University College London, London, UK
}

\begin{abstract}
Climate change studies have been gaining increasing importance in the academic debate, and also in the field of organizations and management. Scholars have contributed to this field by borrowing approaches from sustainable business research. However, some authors have raised unanswered questions about the contribution of these studies to the management theories. According to them, climate change studies have failed to provide theoretical insights and too often they have adopted a descriptive and practical approach. Our review describes the theoretical contribution of the climate change papers, identifying the most often used management theories. The analysis results for 28 different management theories indicate that, while some theories such as the institutional and stakeholder theories have been widely debated, the relation between business climate change strategies and other organization theories still appears to be unexplored. Copyright (c) 2018 John Wiley \& Sons, Ltd and ERP Environment
\end{abstract}

Received 5 July 2017; revised 1 September 2017; accepted 17 September 2017

Keywords: management theories; climate change; literature review; institutional theory; stakeholder theory

\section{Introduction}

LIMATE CHANGE HAS BEEN HOTLY DEBATED IN THE BUSINESS WORLD (IKWUE AND SKEA, 1994). AN INITIAL STRONC OPPOSITION BY many businesses contributed to the delay in negotiations between the USA, Europe and other counterparts in relation to the policies agreed in Kyoto in I997. With increasing regulatory and public pressure, the climate strategies of several companies have now started to change. They have begun to publicly recognize the climate problem, and, especially companies with significant climate change emissions, have started to invest resources in low $\mathrm{CO}_{2}$ emission technologies and renewable energies (Kolk and Levy, 200I).

The inclusion of climate change in companies' strategies has posed major challenges for organization scholars. Adaptation actions have been included in managers' agendas (Jeswani et al., 2008); mitigation actions have been identified as voluntary initiatives to improve corporate reputation (Brouhle and Harrington, 2009; Gasbarro et al., 20I6, 20I7). Climate change is no longer a problem for scientists or territorial planners but has become a field of study for social scientists and corporate management.

The first research in business and climate change focused on corporate involvement in international and political processes (Levy and Egan, 2003; Newell and Paterson, 1998). Other authors then discussed climate change as being 
part of corporate social responsibility strategies (Banerjee, 2008; Le Menestrel and de Bettignies, 2002), in relation to market and strategic dimensions (Weinhofer and Hoffmann, 20I0; Kolk and Pinkse, 2005; Levy and Kolk, 2002) or by analysing the physical impact of climate change on businesses (Hoffman, 2006; Linnenluecke et al., unpublished).

Although many studies have been published in the field of business management and climate change, Goodall (2008) emphasized that the scientific journals related to the Academy of Management did not publish papers on climate change. In her bibliometric study based on the ISI Web of Science database, Goodall selected the top 30 business and management journals with the terms 'climate change' in the title, abstract or keywords of papers published between 1970 and 2006. She found only nine papers published in top business and management journals. Goodall saw this number as being particularly low, not only in absolute terms, but also compared with the papers mentioning 'climate change' published in the top 30 journals of other core social science disciplines such as economics, sociology and political sciences. She put forward various explanations for these results, such as a 'time lag between the discovery of scientific knowledge, its interpretation in the social sciences' and the possibility that 'climate change is a practical problem and not a conceptual one'. Regarding this latter explanation, she suggested that climate change is seen by business and management scholars as a 'non-theoretical' issue and simply as a practical case study. She felt that the social science theoretical models would not facilitate an easy interpretation of empirical analyses in the field (Goodall, 2008). The relation between management theories and climate change has also been debated by other authors.

Similarly, Wittneben et al. (20I2) observed that many papers adopted a descriptive approach focused on identifying corporate responses to climate change without developing a precise theoretical framework to understand companies' strategies and behaviour. They argued that the traditional organizational approaches to address climate change, such as risk management, technological innovation, entrepreneurship and corporate social responsibility, were key limitation in this field of study. In the authors' opinion, to provide the right theoretical framework, scholars should take into account a different set of theoretical perspectives, including political economy, complexity theory, discourse analysis, global and local governance.

Similarly, Hahn et al. (20I0) pointed out the need for novel theoretical approaches to explain the role of business to tackle challenges such as mitigating climate change, alleviating poverty and dealing with migration. Again, Ansari et al. (20II) argued that climate change can offer a fertile ground for organization scholars. Ansari et al. reported that management scholars should rethink the current concepts of climate change, especially through the use of institutional, stakeholder and complexity theories.

Winn et al. (20II) highlighted that organization theorists have not systematically explored the effects of climate change and extreme events on organizations. They observed that management and economics theories have found it difficult 'to recognize (and theorize) the co-dependency between firms and the natural environment'. Other authors have confirmed how, in organizational theory and strategy, the concept of resilience is fairly new (Linnenluecke et al., 20I2; Linnenluecke et al., unpublished). Finally, a recent literature review on carbon disclosure studies (Hahn et al., 20I5) observed that most studies adopt an empirical approach and are rarely grounded in management theories.

Although reviews have been published on corporate sustainability and management theories (e.g. Lozano et al., 20I5), or on climate change and business responses (e.g. Linnenluecke et al., 20I3), there is still a lack of studies on the use of organization and management theories in climate change studies. Our paper aims to address this gap by identifying the main management theories adopted in climate change research and analysing the contribution of these studies to the theories.

The paper proceeds as follows. The following section describes the research method. The next section 3 presents the results, highlighting the use of management theories in climate change studies. The results are then discussed in the fourth section and the last section provides the concluding remarks.

\section{Research Method}

The bibliographic research was carried out on two bibliographic databases (i.e. ISI Web of Science and Scopus). The aim was to identify the climate change studies that contribute to organizational and management theories. Initially, 
the search focused on articles mentioning 'climate change' or 'global warming' associated with the term 'theory' in titles, abstracts and keywords. The results were then filtered by subject area, in order to source articles categorized as business, management and economics. The search was not limited to a specific timespan. Articles were filtered by language, in order to include only international publications in English.

Resulting articles were selected on the basis of references to climate change and management theories contained in the titles and abstracts. This initial phase returned 29 papers referring to 23 distinct theories, as several papers combined more than one theoretical framework. The subsequent searches focused on the specific theories identified in the initial search, by combining 'climate change' or 'global warming' with the specific name of a theory (e.g. 'institutional theory') in the search algorithm. These additional searches led to the selection of 97 papers and to the identification of I7 additional theories. These new theories were therefore included in further theory-specific searches, which led to the selection of II other papers. Finally, additional theories were arbitrarily included in subsequent searches, resulting in 27 papers referencing Io new theories. The bibliographic research therefore identified a total of 153 papers adopting 50 different theories relating to several different disciplines.

The second step involved selecting the theories (and related papers) that could be classified as 'organization and management theories'. As the classification of management theories is open to debate, the selection relied on the diverse classifications already adopted in relevant studies. We used the classifications provided by Colquitt and Zapata-Phelan (2007), Miles (2012), Lozano et al. (2015) and Cornelissen and Durand (20I4). Collectively, these classifications identified 72 organizational and management theories. Theories identified by the former bibliographic research, but not included in the above-mentioned classifications, were excluded from the analysis, as they were considered not pertinent to management theories.

As a result, 28 out of 50 theories emerged as eligible for the analysis. Therefore, the number of articles dropped from the original I53 articles to I3I papers associated with I43 references to the selected 28 organizational and management theories. Table I reports the management theories, and the related number of references to theories, emerging from the bibliographic research.

The final step was to select theories based on the number of times they were referenced in climate change studies. The idea was to limit the analysis to highly relevant theoretical frameworks in the climate change discourse. At the time of the bibliometric research, most of the identified theories were referenced by a single climate change study (Table I). On the other hand, the institutional theory, the theory of planned behaviour (TPB), the stakeholder theory and the transaction cost theory were found to be the most commonly adopted theoretical frameworks (Table I). We decided to select only the theories referenced at least five times by the articles. As a result, Io theories were selected and included in the analysis (Table 2).

\begin{tabular}{|c|c|c|c|c|c|}
\hline Theory & References & Theory & References & Theory & References \\
\hline Absorptive capacity & 4 & Game theory & 6 & Social contract theory & 1 \\
\hline Agency theory & 5 & Organizational learning theory & 6 & Social learning theory & 3 \\
\hline Agenda setting theory & 1 & Planned behaviour theory & 13 & Social network theory & 3 \\
\hline Control theory & 1 & Resource dependence theory & 4 & Structuration theory & 4 \\
\hline $\begin{array}{l}\text { Diffusion of innovation } \\
\text { theory }\end{array}$ & 1 & Resource-based view & 7 & Transaction costs & 12 \\
\hline Dynamic capabilities & 5 & Sense-making theory & 1 & Transformational leadership & 1 \\
\hline Ethical theory & 1 & Social capital theory & 4 & & \\
\hline Evolutionary theory & 1 & Social cognitive theory & 1 & & \\
\hline
\end{tabular}

Table 1. Organizational and management theories with at least one paper published in the field of climate change. 
Selected theories

1. Agency theory
2. Dynamic capabilities
3. Game theory
4. Stakeholder theory
5. Resource-based view

Table 2. Most common organizational and management theories in climate change studies.

\section{Results}

\section{Climate Change and Theoretical Context}

The selection of theories highlights a prevalence of theoretical frameworks pertaining to the strategic management field, signalling a prevailing understanding of climate change as a strategic issue in organizational and management studies, rather than a societal or ethical issue.

First, the theories selected included common theoretical approaches to the corporate social responsibility discourse, such as stakeholder theory (Freeman, I984) and institutional theory (Brammer et al., 20I2). Further influential approaches to strategic management were also included, such as the resource-based view of the firm (Barney, I99I), agency theory (Eisenhardt, I989), organizational learning theory (Fiol and Lyles, I985) and dynamic capabilities (Teece et al., I997). Second, economic approaches to environmental and carbon policy studies include game theory (Rasmusen, I989) and transaction cost theory (Williamson, I98I). Despite adopting economic perspectives, such studies provide both managerial and policy recommendations on key organizational and business issues, such as insurance systems (Porrini and Schwarze, 20I4; de Villemeur and Leroux, 20II), carbon offsetting and trading (González-Ramírez et al., 2012; Cacho et al., 2013) and resource efficiency (Chew et al., 2009). Finally, psychological theories were included, such as the TPB (Ajzen, I985), and behavioural economic theories, such as the prospect theory (Kahneman and Tversky, I979). These theoretical frameworks have been adopted in consumer studies by investigating individual climate-friendly behaviours, such as green consumption (Lin, 2013) and household energy savings (Clement et al., 20I4), as well as individual climate adaptation (Botzen and van den Bergh, 2008).

Table 3 summarizes the theories selected according to the field of study as well as the unit of analysis adopted by the selected articles. The number within brackets indicates the number of articles within the specific field of study, focusing on the specific unit of analysis.

The table shows that some theories are adopted by scholars with a specific unit of analysis and in a specific field of study. In contrast, theories such as institutional and stakeholder demonstrate their capacity to be adapted to different fields and units.

\section{Climate Change Studies with Organizational and Management Approach: The most Frequently Used Theories}

Institutional Theory

Institutional theory addresses the central question of why all organizations in a field tend to look and act the same (DiMaggio and Powell, I983). Institutional theorists define institutions as 'regulative, normative and cognitive structures and activities that provide stability and meaning for social behavior' (Scott, I995). Institutional theory and its evolution as the new institutionalism theory have been widely debated in environmental management studies, and as revealed by Table I this popularity is also found in climate change studies. Scholars have contributed to institutional theory through different kinds of paper: quantitative (Amran et al., 20I6; Orsato et al., 2015; Kolk et al., 2008), qualitative (e.g. Ansari et al., 2013; Garschagen, 2013), and conceptual (Levy and Egan, 2003; Doh and Guay, 2006; Ferraro et al., 2015). Among the quantitative papers, Delmas and Montes-Sancho (20I0) studied the role of institutional pressures in the decisions of companies regarding whether to participate in climate change programs, a specific voluntary agreement being discussed by the authors. Using a multinomial logit model, the authors show that different institutional pressures lead to different firm behaviours: non-cooperation, symbolic 


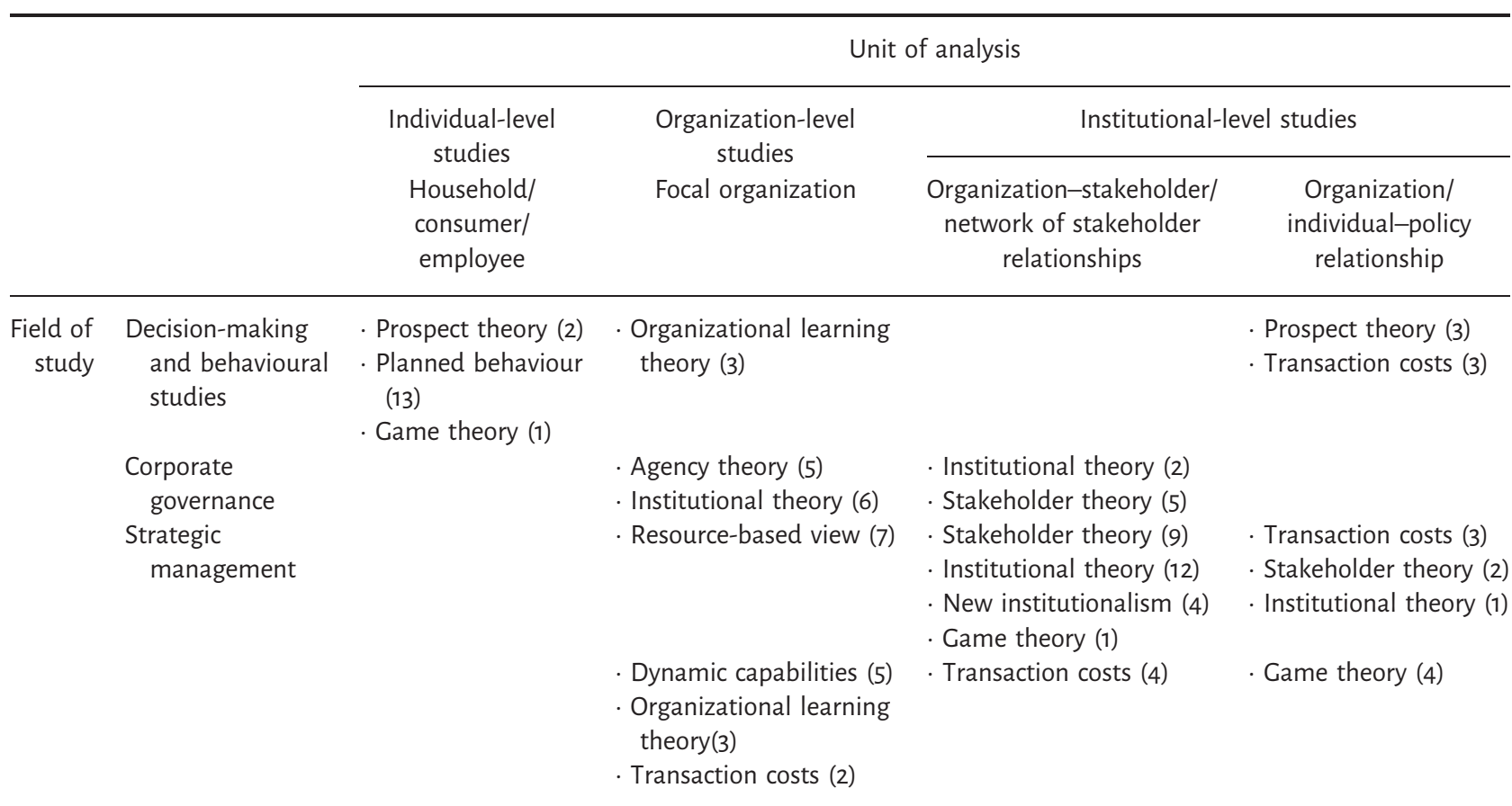

Table 3. Classification of the reviewed papers by field of study and unit of analysis.

cooperation and substantive cooperation behaviour. Similarly, Galbreath (20I0) investigated the link between climate change and institutional theory with a sample of 98 companies from three industries located in ro countries. He observed that coercive pressures play a significant role in the decisions of European companies to address climate change issues. Comyns (2016) focused on the oil and gas industry and highlighted the significant influence of institutional pressures on greenhouse gas (GHG) reporting decisions of multinational companies. Escobar and Vredenburg (20II) also focused on oil and gas multinational companies, but with a qualitative approach. In contrast to the previous paper, they observed that mimetic normative and coercive isomorphism does not play a significant role in the climate change strategies of companies, while mimetic pressures exert a 'slow, rare and discretionary' influence. Again with a qualitative paper, Shinkle and Spencer (20I2) focused on multinational businesses in the automotive industry. The authors analysed the different approaches adopted by firms in order to seek legitimacy. The study confirms that institutional pressures contribute to shaping voluntary carbon disclosures.

\section{Planned Behaviour Theory}

Identifying the cognitive drivers of climate-friendly behavioural change, as well as investigating the interplay among them, has become a significant research stream in management and consumer studies (Tikir and Lehmann, 20II). The TPB (Ajzen, I985) is thus frequently adopted to investigate the cognitive processes underlying several climaterelated behaviours, such as adaptation (Niles et al., 20I6) and mitigation (Thompson and Hansen, 20I2; Lin et al., 20I2). According to the TPB, behavioural intentions are determined by the interplay of an individual's attitude towards a certain behaviour, subjective norms (i.e. the social pressure to perform a certain behaviour) and the perceived ability to control the performance of the behaviour, which is referred to as 'perceived behavioural control' (PBC). In turn, behavioural intentions affect actual behaviour (Ajzen, I985, I991, 2002; Ajzen and Fishbein, 2005). TPB studies on climate change adopt households, citizens or consumers as the unit of analysis, while focusing on individual pro-environmental behaviours as the outcome of the individual cognitive process. For instance, Lin (20I3) surveyed 223 Taiwanese citizens to assess the effects of attitudes towards global warming, subjective norms and PBC on the adoption of five distinct categories of pro-environmental behaviours: personal diet, clothing, housing, transport and recreation. Similarly, van Riper et al. (2013) assessed Australian residents' environmental attitudes and norms as predictors for residents' intention to protect the Great Barrier Reef from harmful climate impacts. 
Numerous studies aim to extend the basic TPB framework, by integrating additional cognitive constructs or combining diverse behavioural models, in order to increase the explanatory power of the theory. Clement et al. (20I4) surveyed college students to investigate the role of subjective norms and PBC in driving the adoption of climate-friendly behaviours, while also accounting for students' concerns, knowledge and beliefs about climate change. Lin (20I5) complemented TPB with the perceived benefit or cost dimension, measuring individual beliefs about the gains or losses produced by a given action, while investigating Taiwanese households' intention to purchase energy-efficient appliances.

Other studies complement TPB with the cultural theory (Tikir and Lehmann, 20II; Leiserowitz, 2006), with the private proactive adaptation to the climate change model (Pröbstl-Haider and Haider, 20I3; Grothmann and Patt, unpublished) and with moral obligations towards pro-environmental behaviour (Chen, 20I6). The results of the above-mentioned studies support the validity of TPB in predicting diverse individual climate-related behaviours in different socio-economic and geographical contexts (Masud et al., 20I6; Scott et al., 20I4). However, some studies highlight the disconnect between intended and reported behaviours (Niles et al., 20I6), and between PBC and behavioural intention (Tikir and Lehmann, 20II).

Stakeholder Theory

Stakeholder theory is one of the most popular management theories and has also been widely debated in the field of sustainable business. The core idea of the theory deals with the role of stakeholders in the definition of company strategies (Hosseini and Brenner, 2015; Donaldson and Preston, I995). According to the theory, the involvement of stakeholders in corporate decisions is not only an ethical approach but also a strategic variable to obtain competitive advantages (Plaza-Úbeda et al., 20ıо; Cennamo et al., 2009). The definition of stakeholders represents the basic concept of the theory. Freeman's landmark book, Strategic Management: a Stakeholder Approach (i984), defined stakeholders as 'individuals or groups who can affect, or are affected by, the actions and results of an organisation'. Subsequently, some authors narrowed this definition or provided different classifications of stakeholders as internal, external and distal (Sirgy, 2002) or primary and secondary (Clarkson, I995).

The theory has been widely used in connection with climate change. Several authors have applied it to analyse and interpret corporate carbon reporting practices. For instance, Comyns (20I6) contributed to the stakeholder theory by assessing the quality and quantity of GHG reports of oil and gas companies. The author analysed 232 reports issued by 45 companies from I998 to 2010 by applying the content analysis research method. According to the study results, the paper did not fully support the theory. The authors observed that political and social pressures on climate issues did not stimulate better reporting practices.

Depoers et al. (2016) did not focus on the quality of GHG reports but on a similar issue: consistency. They analysed data and information included by the same company in two different communication channels: corporate reports and the Carbon Disclosure Project (CDP). According to the stakeholder theory, since these two instruments have different objectives and target stakeholders, they are likely to contain different items of information. Based on IOI observations related to French firms, the authors confirmed their hypothesis: firms tend to report lower GHG emissions in the corporate report than in the CDP, 'customizing' the information according to the targeted stakeholders. Gonzalez-Gonzalez and Zamora Ramírez (20I6) also used CDP data with reference to a sample of Spanish companies. Their paper confirms the validity of the stakeholder theory. Companies subjected to higher pressures from their stakeholders will tend to disclose carbon information in a transparent way in order to maintain legitimacy in the context where they operate.

Some authors have used the CDP data and confirmed the concepts of the stakeholder theory (Liao et al., 20I5; Guenther et al., 20I6). Other authors have combined CDP data with other sources of information obtained from corporate reports and websites (Liesen et al., 20I5) or used CDP data to investigate the relation between stakeholder theory and carbon disclosures by comparing developed and developing countries (Luo et al., 2013).

A more conceptual approach to discuss stakeholder theory in relation to climate change was adopted by Haigh and Griffiths (2009), who debated the possibility of considering the natural environment as a primary stakeholder. They observed how climate change impacts on organizations enable us to observe the relationship between organizations and the natural environment from a less anthropocentric perspective. Kolk and Pinkse (2007) studied the influence of climate change on the strategic management of businesses. They argued that corporate climate strategy depends on the management approach that firms adopt in relation to their stakeholders. The higher the importance 
of stakeholders, the greater the influence on climate strategies. Similarly, Ferraro et al. (20I5) identified climate change as a massive challenge and analysed how stakeholder theorists approached corporate responses to big challenges. According to the authors, the stakeholder theory fails to address the grand challenges because it focuses too much on the interaction between corporations and their stakeholders, without considering other organizations, such as governments, communities and NGOs.

In addition to the two main groups of papers (i.e. on reporting practices and adopting a theoretical approach) just described, other authors have used the stakeholder theory to interpret the results of case studies (Doh and Guay, 2006; Lodhia, 20II) or surveys (Sprengel and Busch, 20II; Raar, 20I5) on businesses' climate strategies.

\section{Transaction Cost Theory}

Transaction costs play a key role in environmental policies according to the literature (Garrick et al., 2013). Some authors, such as McCann (2013), claim that transaction costs should be considered in the design of these kinds of policy. Transaction costs are defined by Coase as the 'costs of negotiating and concluding a separate contract for each exchange transaction' (I937, pp. 39I), and they also include costs relate to information searches, and the monitoring and enforcement of contracts (Arrow, 1969).

Focusing on the role of insurance systems to address climate change, Porrini and Schwarze (20I4) consider transaction costs as a kind of market imperfection. Information and market imperfections are considered when the performance of a number of different insurance systems is analysed. Similarly, de Villemeur and Leroux (20II) proposed a global insurance scheme to share the costs of climate change among countries that are responsible for damage linked to global warming. They state that the proposed insurance scheme should be funded on the basis of different countries' emission levels. Balderas Torres et al. (20I0) take into account transaction costs in the development of cost curves for sequestration options related to agroforestry afforestation and reforestation. The aim is to assess their potential in terms of climate change mitigation. The authors conclude that lower transaction costs impact positively on the development of afforestation and reforestation projects in marginal rural areas. Van Kooten et al. (2002) see afforestation as a means to achieve a carbon emission reduction, and analysed the economic issues linked to afforestation in Canada. The results showed that the transaction costs of this solution are a significant barrier. Similarly, Cacho et al. (2013) state that carbon trades can positively contribute to climate mitigation; however, transaction costs can represent a barrier to carbon markets and trades. The study by Cacho et al. is based on a carbon offset project model applied to two case studies regarding agroforestry and reforestation, and concludes by suggesting ways to reduce transaction costs. González-Ramírez et al. (2012) also considered carbon offsets, and focused on the related agricultural markets for agriculture, taking into account the transaction costs linked to carbon offsets that should be considered by policy makers when designing a carbon offset program. The fact that transaction costs mainly constitute a barrier, is also highlighted by Honlonkou and Hassan (20I5). They reveal that positive effects from environmental instruments are possible for some developing countries, such as the Clean Development Mechanism defined by the Kyoto Protocol, in the case of transaction costs linked to asymmetric information.

Cason and Gangadharan (20II) evaluated the efficiency of linking emission markets through trade emission permits among companies and across regions. The objective was to explore whether, due to direct trade among firms, there is a higher price discovery and a better efficiency in the emission markets than in the case of trades through intermediaries. Their results showed that there is a higher efficiency and abatement of costs in the case of direct trade. Conversely, the presence of intermediaries may increase transaction costs. Going against the views of some scholars, Woerdman (200I) showed that transaction costs are not necessarily higher for some of the Kyoto Mechanisms, such as the Joint Implementation and Clean Development Mechanism, while they may be higher for International Emissions Trading. In addition to studies on transaction costs and climate change conducted in the field of afforestation, there are also case studies on the institutional changes linked to climate change related to the management of the scarcity of cooling water (Eisenack, 20I6). By exploring different regulation options, the study analyses transaction costs, focusing on economies of scale related to transaction costs.

Different perspectives with respect to the above mentioned papers are included in other studies on transaction costs and climate change. One of these is the study of Larson and Breustedt (2009) using a model to explore the drivers of national pilot projects for reducing GHG emissions. They found that transaction costs also influenced the investment decisions related to projects. On the other hand, Oh and Matsuoka (20I6) investigated the effects 
of intellectual property rights on the transfer of environmental technologies. They focused on transaction costs, and reported that intellectual property rights facilitate the technology transfer by, for example, a reduction in transaction costs.

\section{Climate Change Studies with Organizational and Management Approach: Less Frequently Used Theories}

Agency Theory

Agency theory deals with the monitoring and controlling of the relationship between principals and agents. An agency relationship is a contract under which one or more people (the principal/s) engage with another one (the agent) to perform services on their behalf, which involves delegating some decision-making authority to the agent (Amran et al., 20I4, p. I9I). The theory aims to resolve the conflicts that may occur between the principal and the agents.

Although this theory has been used in several fields (Eisenhardt, I989), it has usually been applied to study corporate boards and explore corporate governance. One of the theory's principles is that the structure of boards and the leadership affects company performance: corporate boards should be composed of a greater proportion of outside directors to reduce opportunism and agency costs. In addition, CEO and board chairperson roles should be separated in order to prevent a powerful chief executive from dominating the board (Ingley and van der Walt, 200I). The distinction of roles positively affects company performance. Taking into account the studies on agency theory and climate change, Galbreath (2010) applied this theory by investigating the governance practices of 98 firms in ro countries in order to assess how companies address climate change. Unlike agency theory, the study found that independent boards do not represent the optimal structure to achieve a better governance on climate change. On the other hand, the study confirms the agency theory finding that companies that separate the roles of CEO and board chairperson achieve better governance on climate change. Amran et al. (2OI4) investigated how firms act with regard to climate change disclosure. As in Galbreath's study (20I0), Amran's paper confirms and contradicts the principle of the agency theory on board independence. In line with agency theory, the paper found that an increase in independent non-executive members on the board of directors and the separation of the CEO-board chair role increased the companies' climate change disclosure. However, contrary to agency theory, the results also showed that a lack of gender diversity on the board increased climate change disclosure. Similarly to the study of Amran et al. (20I4), Kalu et al. (20I6) explored carbon disclosure determinants. The study, based on Malaysian real estate companies, showed that agency theory explains one of the determinant aspects for carbon disclosure in developing countries.

Trotman and Trotman (2015) investigated the role of internal audits in the disclosure of GHG emissions and energy through interviews with 29 internal auditors. The study found that the motivations of senior practitioners regarding the internal audit involvement in GHG and energy reporting were in line with main aspects of agency theory.

Finally, Martinez and Bowen (2013) investigated the ethical implications of the United Nation's climate change initiative through agency theory principles. The authors used agency theory to explain positive and negative aspects linked to a waste management project as an example of a climate change initiative through agency theory.

Dynamic Capability Theory

The dynamic capability framework aims to provide a perspective of companies' competitive advantage within dynamic markets and in situations of rapid and unpredictable change (Teece et al., I997). Integrated with the influential resource-based view of the firm, the dynamic capability framework shifts the focus from firms' internal resources to specific strategic and organizational processes (or routines) by which organizations gain, manipulate and combine skills and resources in the pursuit of long-term value-creating strategies and sustained competitive advantage (Eisenhardt and Martin, 2000). According to Kolk and Pinkse (2008), the climate change issue represents a valuable setting for the study of the evolution of multinational enterprises' (MNEs') dynamic capabilities, given the complexity of the issue itself and in view of the diversity of competitive environments, policy frameworks and industries involved. MNEs facing climate-induced disruptions in their business environment deploy dynamic capabilities to develop their competitive advantages (both firm specific and country specific) in order to maintain a fit with the changing business environment. According to a qualitative analysis of CDP data, a climate-induced 
competitive advantage could lead to radical and competence-destroying reconfigurations of firm-specific advantages, as well as to leaner strategic reorientations and competence-enhancing investments, depending on the countryspecific institutional framework and firm-specific technological base (Kolk and Pinkse, 2008). Stechemesser et al. (20I5) provide a similar analysis of CDP data, by focusing on climate change adaptation within the insurance industry. By adopting a dynamic capability perspective, the authors argue that insurance companies' ability to adapt to climate changes results from three main dimensions of dynamic capabilities, namely climate knowledge absorption, climate-related operational flexibility and strategic climate integration (Stechemesser et al., 20I5; Busch, 20II). The authors thus provide a taxonomy of seven main insurance-sector-specific adaptation options within the three aforementioned capabilities. On the other hand, Haney (2015) applies a micro-level perspective on CDP data by focusing on managers' strategic sense-making capacity as a micro-foundation of organizational dynamic capabilities and as a determinant of environmental innovation in the context of climate change. By investigating interpretations of climate issues as threats or opportunities, the author argues that threat interpretations do indeed relate to innovation, when companies are driven by moral legitimacy and are characterized by a long-term perspective on environmental issues (Haney, 20I5).

\section{Came Theory}

Game theory investigates the decisions of individual players to win a game with respect to their competitors. Players are individual agents that act to achieve their limited goals in an abstract setting (Eric, I989). According to the theory there is a certain level of uncertainty due to the fact that players do not fully know what others will do (Miles, 20I2). The theory has been applied in economics and management, but also in accounting, biology, finance, law and political science. Game theory has been also used by a relevant number of articles to explore the definition of international environmental agreements. This can be explained by two factors. First, most environmental issues require actions at a global scale, with the aim to prevent damage to the environment. Despite this, free-riding is one of the most common obstacles to international environmental agreements. With the aim of reducing free-riding, game theory can be a good option to understand 'the strategic considerations of the actors causing transboundary environmental externalities' (Finus, 2008). Second, game theory focuses on the interrelationships among different agents, taking into account assumptions about their preferences and providing potential outcomes of these relationships. In this sense, game theory can be considered as an appropriate tool for studying international environmental agreements 'as they provide a public good with transboundary externalities from which nobody can be excluded' (Finus, 2008).

The theory is based on a player, referred to as a rational, self-interested decision-making subject; a strategy, which consists of the rules of the game; the results of the player's decisions; the payoff, including satisfaction obtained from an outcome of the game, and an equilibrium, which means the optimal game decisions (Rasmusen, I989).

Hou et al. (2015) investigate the effects of the optimal carbon tax and tariff (a comprehensive taxation policy) on the optimal production decisions of companies, by applying a game theory model. The study found that a comprehensive carbon taxation policy benefits developed countries, while a basic policy based on carbon tax is more suitable for developing countries. Covino et al. (2013) explore the reasons for climate change issues using a game theory example and taking into account environmental agreements as a possible solution. The authors use the 'prisoner's dilemma' of game theory to explain the difficulty in achieving agreements at an international level to regulate global warming. Finus (2008) also focuses on international environmental agreements using game theory. The paper highlights the strengths and limitations of applying game theory to an analysis of the international environmental agreements. Eyckmans and Finus (2007) focus on game theory in the context of environmental agreements by using a game theoretical model to improve the success of climate agreements to mitigate climate change.

Chew et al. (2009) use game theory to analyse a solution regarding water conservation as effects of climate change according to an industrial symbiosis approach. The paper uses game theory to explore the interaction among firms in an eco-industrial park to achieve a solution for water conservation and reuse. Gowdy (2008) use game theory to support the view that non-rational behaviours drive human decision making, contrary to the traditional economic view of climate change policy, which affirms rational behaviours as responses to monetary incentives.

Organizational Learning Theory

Organizational learning includes 'the process of improving actions through better knowledge and understanding' (Fiol and Lyles, I985). 
Some studies have applied organizational learning theory to climate change. Dieleman (20I3) focuses on climate change issues in Mexican cities. The author examines organizational learning theory in terms of education and training needs to contribute to the resilience of cities, in order to address climate change. The paper highlights the importance of designing educational and training activities based on organizational learning through eco-cultural innovations. Wamsler et al. (2013) also focus on climate change and urban areas. The aim is to contribute to organizational learning by taking into account theoretical and practical approaches to adaptation planning in cities. Storbjörk (20I0) analyses how organizational learning occurs in climate change adaptation in two municipalities, revealing that there are different learning approaches to climate change in municipalities, but there are similar difficulties in organizational learning, such as a lack of communication and interaction between administrative staff and politicians.

Helgenberger (20II) uses organizational learning theory in the context of business opportunities in the Alpine winter tourism sector in order to understand the processes behind a firm's ability to address climate change issues. The study is based on a qualitative method and finds that the quality of climate information management and the integration of climate change experiences are important in motivating the firm to respond to climate change. Kidd (20II) focuses on climate change and introduceds the potential of organizational learning and knowledge in Asia compared with the West. Applying a consultancy research, Wasdell (20II) examines climate change negotiations in order to contribute to the organizational learning community.

\section{Prospect Theory}

Unlike expected utility theory, prospect theory describes an individual's decision-making processes under the conditions of uncertainty and bounded rationality. Prospect theory assumes that individuals are independent and generally risk-averse agents making deliberate choices, based on the individual's framing of available options. According to Kahneman and Tversky (I979), two main theoretical tenets explain the observed violations of the expected utility rationale under conditions of risk and uncertainty. First, outcomes are framed as gains or losses compared with an individual's 'reference point' or 'baseline scenario', which influence a person's propensity to accept or reject risk. Second, individuals ascribe a disproportionally high value to certain and definite outcomes compared with risky outcomes, due to the 'certainty effect' (Kahneman and Tversky, I979). According to a theoretical paper by Osberghaus (2OI7), prospect theory contributes to the understanding of significant economic puzzles in the climate change debate, such as the different propensity among individuals to undertake actions in favour of climate mitigation and adaptation. If a decision maker perceives the current climate as the reference point, he/she will conceive climate impacts as losses, and adaptation or mitigation as means to reduce such losses. Due to loss aversion, this decision maker will ascribe a higher value to climate mitigation and adaptation compared with an individual who has already shifted his/her reference point to the future climate. Similarly, the choice between different climate policies (adaptation versus mitigation) or even different adaptation measures (technical versus financial) may be reference dependent (Osberghaus, 20I7).

Botzen and van den Bergh (2012) and Botzen et al. (2013) adopt prospect theory to determine households' demand for insurance coverage against climate impacts and natural disasters. According to their empirical studies, a household's willingness to pay for insurance coverage exceeds the expected value of the insurance contract, due to the household's tendency to overweigh low-probability risks under conditions of uncertainty. When confronted with the choice between technical adaptation (e.g. elevation of houses against flood risk) and financial adaptation (i.e. insurance coverage against flood damage), households express a greater willingness to pay for technical measures, if framed as a total elimination of flood risk (Botzen and van den Bergh, 2009, 20I2; Botzen et al., 2013). According to the authors, the 'safety premium' associated with technical adaptation can be explained by the 'certainty effect' and by the expectation that insurance companies may be unable to cover household losses after a flood.

\section{Resource-Based View}

The resource-based view of the firm is a very influential theory in strategic management research, which tries to understand the reasons for a firm's competitive advantages (Barney, I99I). According to the resource-based view, sustained competitive advantage is based on the idiosyncratic and heterogeneous bundles of resources, assets (tangible and intangible) and processes that a firm is able to control (Wernerfelt, I984; Barney et al., 200I). 
Resources deemed as valuable (in terms of exploiting opportunities and/or neutralizing threats), rare, imperfectly imitable and not substitutable enable firms to implement value-creating strategies, which are not duplicable by any current or potential competitor (Barney, I99I; Barney and Clark, 2007). When applied to the study of corporate climate strategies, the resource-based view is frequently combined with the institutional perspective (DiMaggio and Powell, I983) or with the contingency perspective (Ginsberg and Venkatraman, I985) in order to account for external environmental and social pressures that may affect the heterogeneity of climate strategies adopted by different firms (Escobar and Vredenburg, 20II; Amran et al., 20I6; Wahyuni and Ratnatunga, 20I5).

Escobar and Vredenburg (20II) exploit both resource-based and institutional perspectives to study the climate strategies of four multinational oil and gas corporations. Similarly, Amran et al. (2016) adopt this mixed theoretical framework to investigate the impact of internal resources and geographical regional effects on the adoption of climate strategies by companies operating in ASEAN countries. By applying the same theoretical lens, Orsato et al. (2015) investigate the drivers and motivations underpinning the adoption of voluntary climate initiatives among low 'carbon intensity' firms, by focusing on the Brazilian banking industry. According to these studies, while pressures pertaining to the home-country institutional framework may drive companies towards the isomorphic adoption of climate strategies, firm-level factors (such as managerial capabilities, resource slack etc.), as well as host-country-specific factors, affect the integration of climate change into business strategies, determining firmspecific advantages in the execution of climate strategies (Escobar and Vredenburg, 20II; Amran et al., 20ı6; Orsato et al., 2015).

Similar conclusions emerge from the case study of carbon management practices in the Australian energy sector provided by Wahyuni and Ratnatunga (20I5). According to a contingency perspective of the resource-based view, the heterogeneity in environmental performances achieved by a sample of Australian energy companies relies on a combination of contextual factors (namely, sector-specific regulatory contexts and stakeholders' increased carbon consciousness) and firm-specific factors (such as available technological options for mitigation and organizational capabilities) (Wahyuni and Ratnatunga, 2015).

\section{Discussion}

The results of our literature review confirm the findings of previous authors (e.g. Goodall, 2008; Wittneben et al., 20I2) cited in the introduction. Many studies lack a clear theoretical contribution, and only a few organization and management theories are referenced in climate change papers. As already observed by Hahn et al. (2015) in relation to carbon disclosure studies, by focusing on the individual theories our findings confirm that institutional theory and stakeholder theory are among the most frequently used. Our review also includes planned behaviour theory and transaction cost theory, with more than ten climate change papers published. Table 4 shows the research methods adopted by the papers that contribute to the most frequently used theories.

We have not shown all the papers considered with this review because some were not classifiable according to the criteria in Table 4. Thus, for instance, there are 13 climate change studies published in the field of planned behaviour theory as shown in Table I, but only II of them are included in Table 4. This is also the case for Table 6 later.

Quantitative studies are the most common approach adopted for the four theories. Although the numbers of authors and papers are limited, the table reveals that a few authors are present in more than one area. For instance, Kolk has contributed to institutional theory with a quantitative study, and to stakeholder theory with a conceptual paper. Similarly, Lin has two contributions but referring to the same theory (planned behaviour theory) and adopting the same research method (quantitative). The simultaneous contribution to two different theories in the same paper is also rare, and Table 4 highlights only two cases: Doh and Guay (2006) and Comyns (20i6), both contributing together to institutional and stakeholder theories. Focusing on the kind of data used, the authors showed no clear orientation. In the case of institutional theory, the six papers adopting quantitative approaches adopted primary data (e.g. Comyns, 20I6), secondary data (e.g. Delmas and Montes-Sancho 20Io; Galbreath, 20IO) as well as a mix of primary and secondary data (e.g. Amran et al., 20I6; Orsato et al., 20I5). Similarly for stakeholder theory, all the kinds of data are represented and the papers adopt primary data (e.g. Sprengel and Busch, 


\begin{tabular}{|c|c|c|c|c|}
\hline \multirow[t]{2}{*}{$\begin{array}{r}\text { Most frequently } \\
\text { used theories }\end{array}$} & Institutional theory & $\begin{array}{l}\text { Amran et al., 2016; Comyns, } \\
\text { 2016; Delmas and Montes- } \\
\text { Sancho 2010; Galbreath, } \\
\text { 2010; Kolk et al., 2008; } \\
\text { Orsato et al., } 2015\end{array}$ & $\begin{array}{l}\text { Ansari et al., 2013; Escobar } \\
\text { and Vredenburg, 2011; } \\
\text { Garschagen, 2013; Shinkle } \\
\text { and Spencer, } 2012\end{array}$ & $\begin{array}{l}\text { Doh and Guay, 2006; } \\
\text { Ferraro et al., 2015; Levy } \\
\text { and Egan, } 2003\end{array}$ \\
\hline & Stakeholder theory & $\begin{array}{l}\text { Comyns, 2016; Depoers } \\
\text { et al., 2016; Gonzalez- } \\
\text { Gonzalez and Zamora } \\
\text { Ramírez, 2016; Guenther } \\
\text { et al., 2016; Liao et al., } \\
\text { 2015; Liesen et al., 2015; } \\
\text { Luo et al., 2013; Raar, 2015; } \\
\text { Sprengel and Busch, } 2011\end{array}$ & Lodhia, 2011 & $\begin{array}{l}\text { Doh and Guay, 2006; } \\
\text { Ferraro et al., 2015; Haigh } \\
\text { and Griffiths, 2009; Kolk } \\
\text { and Pinkse, } 2007\end{array}$ \\
\hline
\end{tabular}

Table 4. Research methods adopted in the papers that contribute to the most frequently used theories.

20II; Raar, 20I5), secondary data (e.g. Liao et al., 20I5; Guenther et al., 20I6) and primary and secondary data together (e.g. Depoers et al., 20I6; Liesen et al., 20I5). In the case of quantitative studies adopting planned behaviour theory, all the authors used primary data, and also all the papers that contributed to transaction cost theory used secondary data, apart from that by van Kooten et al. (2002), who used a mix of primary and secondary data. CDPs are one of the main sources of data in the field of climate studies. Thus we verified the popularity of CDP among the articles reviewed in our study (Table 5).

CDP is not used particularly frequently as a source of data in the quantitative studies in our review. It represents an important database within the stakeholder theory contributions, but in other cases, such as planned behaviour and transaction costs theories, CDP data have never been used. The findings highlight how some years ago CDP was a widely used database; however, more recently, scholars are collecting data with specific surveys. Similarly to Table 4, Table 6 shows the research approach of papers that contributed to the 'less frequently used theories'.

\begin{tabular}{|c|c|c|c|}
\hline & Theories & CDP & No CDP \\
\hline \multirow[t]{3}{*}{ Most frequently used theories } & Institutional theory & 2 & 4 \\
\hline & Transaction costs & 0 & 5 \\
\hline & Stakeholder theory & 6 & 3 \\
\hline
\end{tabular}

Table 5. Use of CDP data within quantitative papers that adopt the most frequently used theories. 


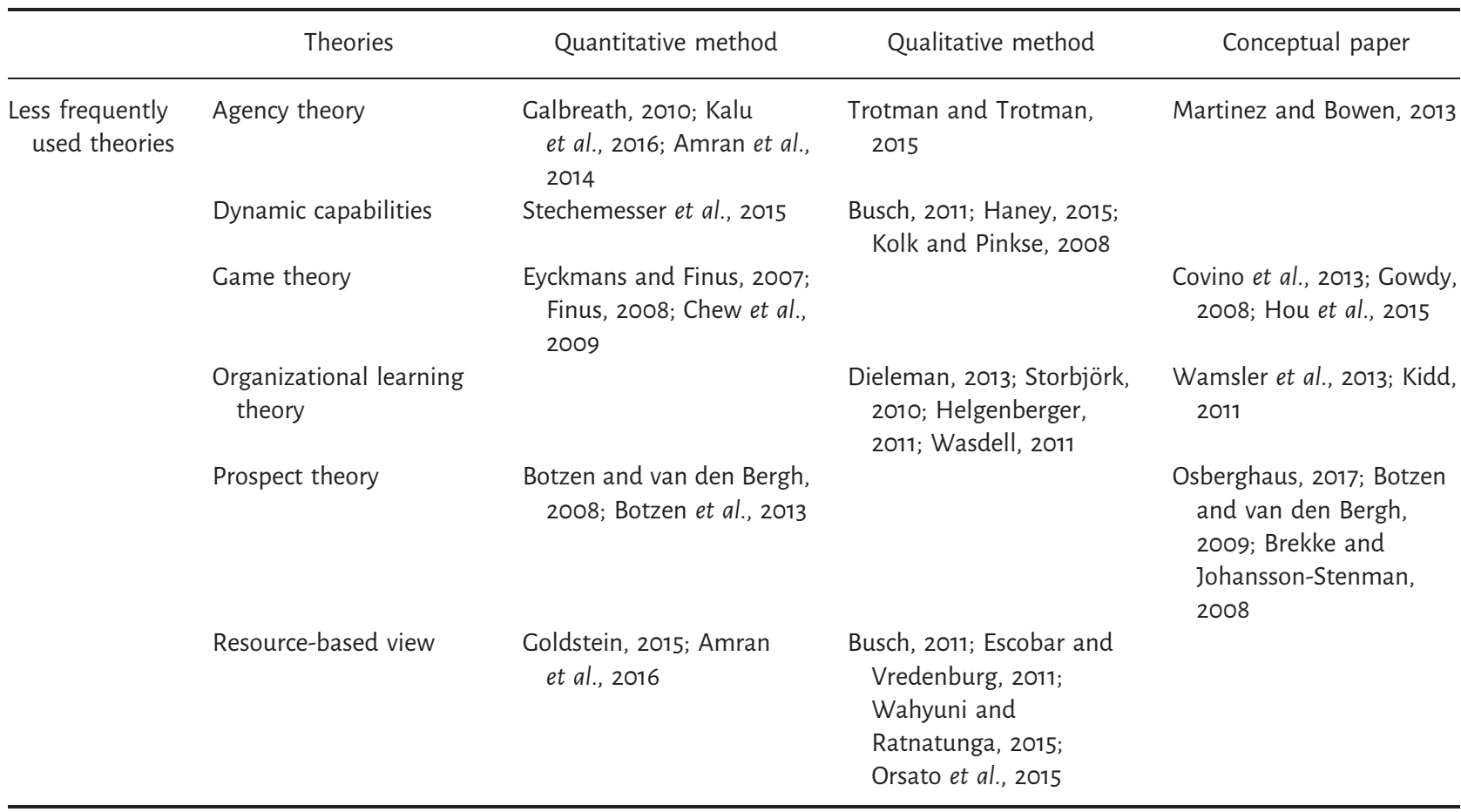

Table 6. Research methods adopted in papers that adopt the less frequently used theories.

Table 6 highlights a balanced distribution among the three categories of research approaches indicated. According to the year of publication, quite surprisingly prospect and game theories were covered in quite old papers. Together with institutional theory (Table 4), these can be considered as the first theories used in the field of climate change studies. In contrast, the studies on absorptive capacity theory, agency theory and planned behaviour theory (Table 4) are more recent. Organizational learning theory has not yet been discussed in a quantitative approach. As shown in Table 4, it is the only theory of the II analysed without a quantitative study. From the authors' point of view, similarly to the most used theories, there are no major contributors to a specific theory. The only exception is the prospect theory: three out of five papers were published by Botzen and van den Bergh from 2008 to 20I3. Finally, with only one qualitative paper, Busch (20II) contributed to two different 'less frequently used theories'. Considering the use of CDP as a source of data for quantitative studies, the results confirm, as in the case of the 'most common theories', a low use of this database. Only two papers used CDP: one related to dynamic capability theory (Stechemesser et al., 20I5) and one that discussed agency theory (Kalu et al., 20I6).

Finally, we investigated the conclusions of each paper with particular focus on understanding whether or not the papers support the theory and/or in some cases extend it (Table 7).

Although the majority of papers confirm the theory discussed, some papers do not support the theories, or the results appear unclear. For instance, for planned behaviour theory, the number of papers that do not confirm the theory is higher than the number supporting it. In addition, the general results of this literature review highlight a parallel between the scientific contribution and international climate change negotiations. In 2009 the Copenhagen Agreement was not adopted as a United Nations decision, and this failure in the negotiations is mirrored by Table 7: only seven papers were published between 2009 and 20I0. Conversely, the agreements reached on II December at the 20I0 United Nations Climate Change Conference in Cancun represented a key step forwards in the climate change negotiations. Again, in terms of the papers included in Table 7 and published in 2OII and 20I2, there are I7 contributions, Io papers more the previous two years. This positive period of contribution is also confirmed by the high number of papers published in 20I3. Although it is too soon to assess the success of the Paris Agreement adopted in December 20I5, a higher number of contributions is expected in the coming years. This 


\begin{tabular}{|c|c|c|c|}
\hline \multirow[t]{4}{*}{$\begin{array}{l}\text { Most } \\
\text { frequently } \\
\text { used theories }\end{array}$} & Institutional theory & $\begin{array}{l}\text { Amran et al., 2016; Ansari et al., 2013; } \\
\text { Comyns, 2016; Delmas and Montes- } \\
\text { Sancho 2010; Doh and Guay, 2006; } \\
\text { Ferraro et al., 2015; Galbreath, 2010; } \\
\text { Garschagen, 2013; Kolk et al., 2008; } \\
\text { Levy and Egan, 2003; Orsato et al., } \\
\text { 2015; Shinkle and Spencer, } 2012\end{array}$ & Escobar and Vredenburg 2011 \\
\hline & $\begin{array}{l}\text { Planned behaviour } \\
\text { theory }\end{array}$ & $\begin{array}{l}\text { Chen, 2016; van Riper et al., 2013; } \\
\text { Pröbstl-Haider and Haider, 2013; } \\
\text { Lin et al., 2012; Tikir and Lehmann, } 2011\end{array}$ & $\begin{array}{l}\text { Niles et al., 2016; Masud et al., 2016; } \\
\text { Scott et al., 2014; Clement et al., } \\
\text { 2014; Lin, 2013; Thompson and } \\
\text { Hansen, } 2012\end{array}$ \\
\hline & Transaction costs & $\begin{array}{l}\text { Cacho et al., 2013; Cason and } \\
\text { Gangadharan, 2011; Honlonkou } \\
\text { and Hassan, 2015; de Villemeur } \\
\text { and Leroux, 2011; Eisenack, 2016; } \\
\text { Conzález-Ramírez et al., 2012; } \\
\text { Larson and Breustedt, 2009; Oh } \\
\text { and Matsuoka, 2016; Porrini and } \\
\text { Schwarze, 2014; van Kooten et al., } \\
2002\end{array}$ & $\begin{array}{l}\text { Balderas Torres et al., 2010; } \\
\text { Woerdman, } 2001\end{array}$ \\
\hline & Stakeholder theory & $\begin{array}{l}\text { Gonzalez-Gonzalez and Zamora } \\
\text { Ramírez, 2016; Liao et al., 2015; } \\
\text { Guenther et al., 2016; Depoers } \\
\text { et al., 2016; Liesen et al., 2015; } \\
\text { Kolk and Pinkse, 2007; Lodhia, } \\
\text { 2011; Sprengel and Busch, 2011; } \\
\text { Raar, 2015; Doh and Guay, 2006; } \\
\text { Luo et al., 2013; Haigh and } \\
\text { Griffiths, 2009; Ferraro et al., } 2015\end{array}$ & Comyns, 2016 \\
\hline \multirow{4}{*}{$\begin{array}{l}\text { Less frequently } \\
\text { used theories }\end{array}$} & Game theory & $\begin{array}{l}\text { Eyckmans and Finus, 2007; Finus, } \\
\text { 2008; Chew et al., 2009; Covino } \\
\text { et al., 2013; Gowdy, 2008; Hou } \\
\text { et al., } 2015\end{array}$ & \\
\hline & Organizational learning theory & $\begin{array}{l}\text { Dieleman, 2013; Wamsler et al., 2013; } \\
\text { Storbjörk, 2010; Kidd, } 2011\end{array}$ & Wasdell, 2011; Helgenberger, 2011 \\
\hline & Prospect theory & $\begin{array}{l}\text { Botzen and van den Bergh, 2008, } \\
\text { Botzen et al., 2013; Osberghaus, 2017; } \\
\text { Botzen and van den Bergh, 2009; } \\
\text { Brekke and Johansson-Stenman, } 2008\end{array}$ & \\
\hline & $\begin{array}{l}\text { Resource-based view of the } \\
\text { firm }\end{array}$ & $\begin{array}{l}\text { Busch, 2011; Wahyuni and } \\
\text { Ratnatunga, 2015; Escobar and } \\
\text { Vredenburg, 2011; Orsato et al., } 2015\end{array}$ & Amran et al., 2016 \\
\hline
\end{tabular}

Table 7. Contributions to the theories of the papers reviewed.

positive future trend would seem to be confirmed by the nine papers published in 20I6. Future papers linked with the Paris Agreement could be expected, for instance contributing to game theory, since it is based on the study of conflict and cooperation among actors or countries. 


\section{Conclusions}

The aim of our paper was to investigate the criticism raised by some authors regarding a low use and contribution to management theories from climate change studies. This paper offers some insights related to this field of study.

First, our paper confirms the concern raised by the literature, although in the last few years the number of climate change studies based on management theories has been increasing. Nevertheless, if we compare the number of organizational and management theories identified (72) with the number of theories used in at least five papers (Iо), there is still a wide gap. We invite scholars involved in climate change studies to explore more connections between climate strategies and management theories in future research.

Second, among the few management theories explored, some such as institutional, stakeholder and planned behaviour theories were shown to have more appeal for climate change scholars. Future studies could explore the reasons for this phenomenon.

Finally, regarding the published results, almost all the papers confirmed the theories they used and only a few tried to extend the concepts involved. We invite future authors to be more courageous in their approach by updating and broadening the theories explored.

The main limitation of our study is that we considered the number of papers in absolute terms without a benchmark to compare our findings. Unfortunately, a similar review on the use of management theories for example related to the wider field of sustainability management does not exist in the literature. A similar future study could help to better support our conclusions.

\section{References}

Ajzen I. I985. From intentions to actions: a theory of planned behavior. In Action Control, Kuhl J, Beckmann J (eds). Springer: Heidelberg; II-39.

Ajzen I. I99I. The theory of planned behavior. Organizational Behavior and Human Decision Processes 50: I79-2II. https://doi.org/IO.IoI6/o7495978(91)90020-T

Ajzen I. 2002. Perceived behavioral control, self-efficacy, locus of control, and the theory of planned behavior. Journal of Applied Social Psychology 8०(6): 29I8-2940. https://doi.org/I0.IIII/j.I559-18I6.2002.tboo236.x

Ajzen I, Fishbein M. 2005. The influence of attitudes on behavior. The handbook of attitudes I73(22I): 3I.

Amran A, Ooi SK, Wong CY, Hashim F. 20I6. Business strategy for climate change: an ASEAN perspective. Corporate Social Responsibility and Environmental Management 23(4): 213-227. https://doi.org/I0.1002/csr.I37I

Amran A, Periasamy V, Zulkafli AH. 20I4. Determinants of climate change disclosure by developed and emerging countries in Asia Pacific. Sustainable Development 22: 188-204.

Ansari S, Gray B, Wijen F. 20II. Fiddling while the ice melts? How organizational scholars can take a more active role in the climate change debate. Strategic Organization 9: 70-76.

Ansari S, Wijen F, Gray B. 20I3. Constructing a climate change logic: An institutional perspective on the "tragedy of the commons". Organization Science 24(4): IOI4-I040.

Arrow K. I969. The economics of agency. In Principals and Agents: the Structure of Business, Pratt JW, Zeckhauser RJ (eds). Harvard Business School Press: Boston, MA; 37-5I.

Balderas Torres A, Marchant R, Lovett JC, Smart JCR, Tipper R. 20Io. Analysis of the carbon sequestration costs of afforestation and reforestation agroforestry practices and the use of cost curves to evaluate their potential for implementation of climate change mitigation. Ecological Economics 69: 469-477.

Banerjee SB. 2008. Corporate social responsibility: the good, the bad and the ugly. Critical Sociology 34(I): 5I-79.

Barney J. I99I. Firm resources and sustained competitive advantage. Journal of Management I7(I): 99-I20.

Barney J, Wright M, Ketchen DJ Jr. 200I. The resource-based view of the firm: ten years after I99I. Journal of Management 27(6): 625-64I.

Barney JB, Clark DN. 2007. Resource-based theory: Creating and sustaining competitive advantage. Oxford University Press on Demand.

Botzen WJW, van den Bergh JCJM. 2008. Insurance against climate change and flooding in the Netherlands: Present, future, and comparison with other countries. Risk Analysis 28(2): 413-426. https://doi.org/IO.IIII/j.I539-6924.2008.01035.x

Botzen WJ, van den Bergh JC. 20I2. Risk attitudes to low-probability climate change risks: WTP for flood insurance. Journal of Economic Behavior and Organization 82(I): I5I-I66.

Botzen WJW, Aerts JCJH, van den Bergh JCJM. 20I3. Individual preferences for reducing flood risk to near zero through elevation. Mitigation and Adaptation Strategies for Global Change I8(2): 229-244. https://doi.org/I0.I007/si1027-012-9359-5

Botzen WJW, van den Bergh JCJM. 2009. Managing natural disaster risks in a changing climate. Environmental Hazards 8(3): 209-225.

Brammer S, Jackson G, Matten D. 20I2. Corporate social responsibility and institutional theory: new perspectives on private governance. Socioeconomic Review Io(I): 3-28.

Brekke KA, Johansson-Stenman O. 2008. The behavioural economics of climate change. Oxford Review of Economic Policy 24(2): $280-297$. 
Brouhle K, Harrington DR. 2009. Firm strategy and the Canadian voluntary climate challenge and registry (VCR). Business Strategy and the Environment I8(6): 360-379.

Busch T. 20II. Organizational adaptation to disruptions in the natural environment: the case of climate change. Scandinavian Journal of Management 27: 389-404.

Cacho OJ, Lipper L, Moss J. 20I3. Transaction costs of carbon offset projects: a comparative study. Ecological Economics 88: $232-243$.

Cason TN, Gangadharan L. 20II. Price discovery and intermediation in linked emissions trading markets: a laboratory study. Ecological Economics 70: I424-I433.

Cennamo C, Berrone P, Gomez-Mejia LR. 2009. Does stakeholder management have a dark side? Journal of Business Ethics 89(4): 49I-507.

Chen MF. 20I6. Extending the theory of planned behavior model to explain people's energy savings and carbon reduction behavioral intentions to mitigate climate change in Taiwan - moral obligation matters. Journal of Cleaner Production II2: I746-I753. https://doi.org/IO.IoI6/j. jclepro.20I5.07.043

Chew IML, Tan RR, Foo DCY, Chiu ASF. 2009. Game theory approach to the analysis of inter-plant water integration in an eco-industrial park. Journal of Cleaner Production I7: IGII-I6I9.

Clarkson MBE. I995. A stakeholder framework for analyzing and evaluating corporate social performance. Academy of Management Review 20(I): 92-II7.

Clement CA, Henning JB, Osbaldiston R. 20I4. Integrating factors that predict energy conservation: the theory of planned behavior and beliefs about climate change. Journal of Sustainable Development $7(6): 46$.

Coase RH. I937. The nature of the firm. Economica 4(I6): 386-405.

Colquitt JA, Zapata-Phelan CP. 2007. Trends in theory building and theory testing: A five-decade study of the "Academy of Management Journal". The Academy of Management Journal I28I-I303.

Comyns B. 20I6. Determinants of GHG reporting: an analysis of global oil and gas companies. Journal of Business Ethics 136(2): 349-369.

Cornelissen JP, Durand R. 20I4. Moving forward: developing theoretical contributions in management studies. Journal of Management Studies 5I(6): 995-I022.

Covino D, Boccia F, Sarno V. 20I3. Global warming and environmental agreements. Quality - Access to Success Supplement 4I-45. 5p.

de Villemeur ÉB, Leroux J. 20II. Sharing the cost of global warming. Scandinavian Journal of Economics II3(4): 758-783.

Delmas MA, Montes-Sancho MJ. 20I0. Voluntary agreements to improve environmental quality: Symbolic and substantive cooperation. Strategic Management Journal 3I(6): 575-60I.

Depoers F, Jeanjean T, Jérôme T. 20I6. Voluntary disclosure of greenhouse gas emissions: Contrasting the carbon disclosure project and corporate reports. Journal of Business Ethics I34(3): 445-46r.

Dieleman H. 20I3. Organizational learning for resilient cities, through realizing eco-cultural innovations. Journal of Cleaner Production 50: I7I-I80.

DiMaggio P, Powell WW. I983. The iron cage revisited: institutional isomorphism and collective rationality in organizational fields. American Sociological Review 48: 147-160.

Doh JP, Guay TR. 2006. Corporate social responsibility, public policy, and NGO activism in Europe and the United States: an institutionalstakeholder perspective. Journal of Management Studies 43(I): 47-73.

Donaldson T, Preston LE. I995. The stakeholder theory of the corporation: concepts, evidence, and implications. Academy of Management Review 20(I): 65-9I.

Eisenack K. 20I6. Institutional adaptation to cooling water scarcity for thermoelectric power generation under global warming. Ecological EconomiCS I24: $153-163$.

Eisenhardt KM. I989. Agency theory: an assessment and review. Academy of Management Review I4(I): 57-74.

Eisenhardt KM, Martin JA. 2000. Dynamic capabilities: what are they? Strategic Management Journal 2I(IO/II): IIO5-II2I.

Eric R. I989. Games and Information: an Introduction to Game Theory.

Escobar LF, Vredenburg H. 2oIr. Multinational oil companies and the adoption of sustainable development: a resource-based and institutional theory interpretation of adoption heterogeneity. Journal of Business Ethics 98(I): 39-65.

Eyckmans J, Finus M. 2007. Measures to enhance the success of global climate treaties. International Environmental Agreements: Politics, Law and Economics 7(I): 73-97.

Ferraro F, Etzion D, Gehman J. 2015. Tackling grand challenges pragmatically: robust action revisited. Organization Studies 36(3): 363-390.

Finus M. 2008. Game theoretic research on the design of international environmental agreements: insights, critical remarks, and future challenges. International Review of Environmental and Resource Economics 2: 29-67.

Fiol CM, Lyles MA. I985. Organizational learning. Academy of Management Review Io(4): 803-813.

Freeman RE. 1984. Strategic Management: a Stakeholder Approach. Pitman: Boston, MA.

Galbreath J. 20I0. Corporate governance practices that address climate change: an exploratory study. Business Strategy and the Environment I9: $335-350$.

Garrick D, McCann L, Pannell DJ. 20I3. Transaction costs and environmental policy: taking stock, looking forward. Ecological Economics 88: I82-I84.

Garschagen M. 20I3. Resilience and organisational institutionalism from a cross-cultural perspective: an exploration based on urban climate change adaptation in Vietnam. Natural Hazards 67(I): 25-46.

Gasbarro F, Iraldo F, Daddi T. 20I7. The drivers of multinational enterprises' climate change strategies: a quantitative study on climate-related risks and opportunities. Journal of Cleaner Production 160: 8-26.

Gasbarro F, Rizzi F, Frey M. 20I6. Adaptation measures of energy and utility companies to cope with water scarcity induced by climate change. Business Strategy and the Environment 25(I): 54-72. 
Ginsberg A, Venkatraman N. I985. Contingency perspectives of organizational strategy: a critical review of the empirical research. Academy of Management Review Io(3): 42I-434.

Goldstein D. 2015. Climate-adaptive technological change in a small region: A resource-based scenario approach. Technological Forecasting and Social Change 99: I68-I80. https://doi.org/I0.I0I6/j.techfore.20I5.04.0I4

Gonzalez-Gonzalez JM, Zamora Ramírez C. 20I6. Voluntary carbon disclosure by Spanish companies: an empirical analysis. International Journal of Climate Change Strategies and Management 8(I): 57-79.

González-Ramírez J, Kling CL, Valcu A. 20I2. An overview of carbon offsets from agriculture. Annual Review of Resource Economics 4(I): I45-I6o.

Goodall AH. 2008. Why have the leading journals in management (and other social sciences) failed to respond to climate change? Journal of Management Inquiry I7(4): 408-420.

Gowdy JM. 2008. Behavioral economics and climate change policy. Journal of Economic Behavior and Organization 68: 632-644.

Guenther E, Guenther T, Schiemann F, Weber G. 20I6. Stakeholder relevance for reporting: explanatory factors of carbon disclosure. Business and Society 55(3): $36 \mathrm{I}-397$.

Hahn R, Reimsbach D, Schiemann F. 20I5. Organizations, climate change, and transparency: reviewing the literature on carbon disclosure. Organization and Environment 28(I): 80-IO2.

Hahn T, Kolk A, Winn M. 20I0. A new future for business? Rethinking management theory and business strategy. Business and Society 49(3): 385-40I.

Haigh N, Griffiths A. 2009. The natural environment as a primary stakeholder: the case of climate change. Business Strategy and the Environment I8: $347-359$.

Haney AB. 20I5. Threat interpretation and innovation in the context of climate change: an ethical perspective. Journal of Business Ethics I43(2): $26 \mathrm{I}-276$.

Helgenberger S. 20II. The capacity of locally bound tourism firms to respond to climate variability and long-term change: qualitative case studies on organizational learning in the Austrian winter tourism sector. Tourism Planning and. Development 8(I): 69-86.

Hoffmann AJ. 2006. Getting ahead of the curve: Corporate strategies that address climate change (pp. 2I-5I). Pew Center on Global Climate Change: Arlington, VA.

Honlonkou AN, Hassan RM. 20I5. Developing countries' response to the clean development mechanism under imperfect information and transaction costs. Climate Change Economics 6(I): I55000I-I-I55000I-22.

Hosseini JC, Brenner SN. 20I5. The stakeholder theory of the firm: a methodology to generate value matrix weights. Business Ethics Quarterly 2(2): 99-II9.

Hou Y, Jia M, Tian X, Wei F, Wei K. 20I5. Optimal decisions of countries with carbon tax and carbon tariff. Journal of Industrial Engineering and Management 8(3): 98I-IOOI.

Ikwue T, Skea J. I994. Business and the genesis of the European community carbon tax proposal. Business Strategy and the Environment 3(2): I-Io.

Ingley CB, van der Walt NT. 200I. The strategic board: the changing role of directors in developing and maintaining corporate capability. Corporate Governance 9: $174-185$.

Jeswani HK, Wehrmeyer W, Mulugetta Y. 2008. How warm is the corporate response to climate change? Evidence from Pakistan and the UK. Business Strategy and the Environment I7(I): 46-60.

Kahneman D, Tversky A. I979. Prospect theory: An analysis of decision under risk. In handbook of the fundamentals of financial decision making: Part I (pp. 99-I27).

Kalu JU, Buang A, Aliagha GU. 20I6. Determinants of voluntary carbon disclosure in the corporate real estate sector of Malaysia. Journal of Environmental Management 182: 519-524.

Kidd JB. 20II. Organisational learning, climate change and the tragedy of the commons in China. International Intellectual Journal of Learning and Capital 8(2): 222-238.

Kolk A, Levy D. 200I. Winds of change: corporate strategy, climate change and oil multinationals. European Management Journal I9(5): 50I-509.

Kolk A, Levy D, Pinkse J. 2008. Corporate responses in an emerging climate regime: the institutionalization and commensuration of carbon disclosure. European Accounting Review I7(4): 719-745.

Kolk A, Pinkse J. 2005. Business response to climate change: identifying emergent strategies. California Management Review 47(3): 6-20.

Kolk A, Pinkse J. 2007. Towards strategic stakeholder management? Integrating perspectives on sustainability challenges such as corporate responses to climate change. Corporate Governance 7(4): 370-378.

Kolk A, Pinkse J. 2008. A perspective on multinational enterprises and climate change: learning from 'An Inconvenient Truth'? Journal of International Business Studies 39(8): 1359-1378.

Larson DE, Breustedt G. 2009. Will markets direct investments under the Kyoto Protocol? Lessons from the activities implemented jointly pilots. Environmental and Resource Economics 43: 433-456.

Le Menestrel M, de Bettignies HC. 2002. Processes and consequences in business ethical dilemmas: the oil industry and climate change. Journal of Business Ethics 4I(3): 25I-266.

Leiserowitz A. 2006. Climate change risk perception and policy preferences: the role of affect, imagery, and values. Climatic Change $77(\mathrm{I}): 45-72$.

Levy DL, Egan D. 2003. A neo-Gramscian approach to corporate political strategy: conflict and accommodation in the climate change negotiations. Journal of Management Studies 40(4): 803-830.

Levy DL, Kolk A. 2002. Strategic responses to global climate change: conflicting pressures on multinationals in the oil industry. Business and Politics 4(3): 275-300.

Liao L, Luo L, Tang Q. 20I5. Gender diversity, board independence, environmental committee and greenhouse gas disclosure. British Accounting Review 47: 409-424.

Liesen A, Hoepner AG, Patten DM, Figge F. 20I5. Does stakeholder pressure influence corporate GHG emissions reporting? Empirical evidence from Europe. Accounting, Auditing \& Accountability Journal 28(7): 1047-I074. 
Lin JC, Wu CS, Liu WY, Lee CC. 20I2. Behavioral intentions toward afforestation and carbon reduction by the Taiwanese public. Forest Policy and Economics I4(I): II9-I26. https://doi.org/І0.I0I6/j.forpol.20II.07.016

Lin SP. 2013. The gap between global issues and personal behaviors: pro-environmental behaviors of citizens toward climate change in Kaohsiung, Taiwan. Mitigation and Adaptation Strategies for Global Change 18(6): 773-783.

Lin SP. 2015. Raising public awareness: the role of the household sector in mitigating climate change. International Journal of Environmental Research and Public Health I2(10): 13162-13178. https://doi.org/10.3390/ijerphi21013162

Linnenluecke MK, Griffiths A, Winn M. 20I2. Extreme weather events and the critical importance of anticipatory adaptation and organizational resilience in responding to impacts. Business Strategy and the Environment 2I(I): I7-32.

Linnenluecke MK, Griffiths A, Winn MI. 20I3. Firm and industry adaptation to climate change: a review of climate adaptation studies in the business and management field. Wiley Interdisciplinary Reviews: Climate Change 4(5): 397-4I6.

Lodhia SV. 20II. Risk and management of climate induced disasters in coastal Gujarat in India. Management of Environmental Quality 23(I): 82-IOO.

Lozano R, Carpenter A, Huisingh D. 20I5. A review of 'theories of the firm' and their contributions to corporate sustainability. Journal of Cleaner Production I06: 430-442.

Luo L, Tang Q, Lan Y-C. 2013. Comparison of propensity for carbon disclosure between developing and developed countries: a resource constraint perspective. Accounting Research Journal 26(I): 6-34.

Martinez CA, Bowen JD. 20I3. The ethical challenges of the UN's clean development mechanism. Journal of Business Ethics II7: 807-82I.

Masud MM, Al-Amin AQ, Junsheng H, Ahmed F, Yahaya SR, Akhtar R, Banna H. 20I6. Climate change issue and theory of planned behaviour: relationship by empirical evidence. Journal of Cleaner Production II3: 613-623. https://doi.org/Io.I0I6/j.jclepro.20I5.II.080

McCann L. 20I3. Transaction costs and environmental policy design. Ecological Economics 88: 253-262.

Miles JA. 20I2. Management and Organization Theory: a Jossey-Bass Reader, 9. John Wiley \& Sons: Hoboken, New Jersey (USA).

Newell P, Paterson M. I998. A Climate for Business: Global Warming, the State and Capital. Review of International Political Economy 5(4): 679-703.

Niles MT, Brown M, Dynes R. 20I6. Farmer's intended and actual adoption of climate change mitigation and adaptation strategies. Climatic Change I35(2): 277-295. https://doi.org/10.1007/sio584-015-I558-0

Oh C, Matsuoka S. 20I6. Complementary approaches to discursive contestation of the effects of the IPR regime on technology transfer in the face of climate change. Journal of Cleaner Production I28: I68-I77.

Orsato RJ, De Campos JGF, Barakat SR, Nicolletti M, Monzoni M. 20I5. Why join a carbon club? A study of the banks participating in the Brazilian 'Business for Climate Platform. Journal of Cleaner Production 96: 387-396.

Osberghaus D. 20I7. Prospect theory, mitigation and adaptation to climate change. Journal of Risk Research 20(7): 909-930.

Plaza-Úbeda JA, de Burgos-Jiménez J, Carmona-Moreno E. 2oIo. Measuring stakeholder integration: knowledge, interaction and adaptational behavior dimensions. Journal of Business Ethics 93(3): 4I9-442.

Porrini D, Schwarze R. 20I4. Insurance models and European climate change policies: an assessment. European Journal of Law and Economics 38(I): 7-28.

Pröbstl-Haider U, Haider W. 2013. Tools for measuring the intention for adapting to climate change by winter tourists: some thoughts on consumer behavior research and an empirical example. Tourism Review 68(2): 44-55.

Raar J. 20I5. SMEs, environmental management and global warming: a fusion of influencing factors? Journal of Small Business and Enterprise Development 22(3): $528-548$.

Rasmusen E. I989. An Introduction to Game Theory. John Wiley \& Sons: Hoboken, New Jersey (USA)

Scott FL, Jones CR, Webb TL. 20I4. What do people living in deprived communities in the UK think about household energy efficiency interventions? Energy Policy 66: 335-349. https://doi.org/10.1016/j.enpol.2013.10.084

Scott WR. I995. Institutions and Organisations. Sage: Thousand Oaks, CA.

Shinkle GA, Spencer JW. 20I2. The social construction of global corporate citizenship: sustainability reports of automotive corporations. Journal of World Business 47(I): 123-I33.

Sirgy MJ. 2002. Measuring corporate performance by building on the stakeholders model of business ethics. Journal of Business Ethics 35(3): I43-I62.

Sprengel DC, Busch T. 20II. Stakeholder engagement and environmental strategy - the case of climate change. Business Strategy and the Environment 20: $35 \mathrm{I}-364$.

Stechemesser K, Endrikat J, Grasshoff N, Guenther E. 20I5. Insurance companies' responses to climate change: adaptation, dynamic capabilities and competitive advantage. Geneva Papers on Risk and Insurance: Issues and. Practice 40(4): 557-584.

Storbjörk S. 20I0. 'It takes more to get a ship to change course': barriers for organizational learning and local climate adaptation in Sweden. Journal of Environmental Policy and Planning I2(3): 235-254.

Teece DJ, Pisano G, Shuen A. I997. Dynamic capabilities and strategic management. Strategic Management Journal I8(7): 509-533.

Thompson DW, Hansen EN. 20I2. Institutional pressures and an evolving forest carbon market. Business Strategy and the Environment 2I(6): 35I-369. https://doi.org/I0.I002/bse.I726

Tikir A, Lehmann B. 20II. Climate change, theory of planned behavior and values: a structural equation model with mediation analysis. Climatic Change 104(2): 389-402. https://doi.org/10.1007/sio584-010-9937-Z

Trotman AJ, Trotman KT. 20I5. Internal audit's role in GHG emissions and energy reporting: evidence from audit committees, senior accountants, and internal auditors. Auditing: a Journal of Practice and Theory 34(I): 199-230.

van Kooten GC, Lee Shaikh S, Suchánek P. 2002. Mitigating climate change by planting trees: the transaction costs trap. Land Economics 78 (4): $559-572$. 
van Riper CJ, Kyle GT, Sutton SG, Yoon JI, Tobin RC. 20I3. Australian residents' attitudes toward pro-environmental behaviour and climate change impacts on the Great Barrier Reef. Journal of Environmental Planning and Management 56(January): 494-5II.

Wahyuni D, Ratnatunga J. 20I5. Carbon strategies and management practices in an uncertain carbonomic environment - lessons learned from the coal-face. Journal of Cleaner Production 96: 397-406.

Wamsler C, Brink E, Rivera C. 20I3. Planning for climate change in urban areas: from theory to practice. Journal of Cleaner Production 50: 68-8I. Wasdell D. 20II. The dynamics of climate change: a case study in organisational learning. Learning. Organization I8(I): IO-20.

Weinhofer G, Hoffmann VH. 20I0. Mitigating climate change - how do corporate strategies differ? Business Strategy and the Environment I9(2): $77-89$.

Wernerfelt B. I984. A resource-based view of the firm. Strategic Management Journal 5(2): I7I-I80.

Williamson OE. I98I. The economics of organization: the transaction cost approach. American Journal of Sociology 87(3): 548-577.

Winn MI, Kirchgeorg M, Griffi A, Linnenluecke MK, Günther E. 20II. Impacts from climate change on organizations: a conceptual foundation. Business Strategy and the Environment 20: 157-I73.

Wittneben BBF, Okereke C, Banerjee SB, Levy DL. 20I2. Climate change and the emergence of new organizational landscapes. Organization Studies 33(II): I43I-I450.

Woerdman E. 200I. Emissions trading and transaction costs: analysing the flaws in the discussion. Ecological Economics 38: $293-304$. 